\title{
Techno-Economic Potential of Largescale Photovoltaics in Bahrain
}

\author{
Gobind Pillai ${ }^{a^{*}}$, Husain Ali Yaqoob Naser ${ }^{b}$ \\ aSchool of Science, Engineering and Design, Teesside University, Middlesbrough, UK.

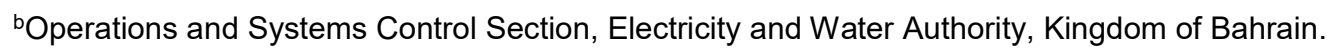 \\ "Corresponding author, Email: G.G.Pillai@tees.ac.uk
}

\section{Highlights}

1. Techno-economic analysis for a largescale PV system optimised for peak-load matching.

2. Levelised cost of electricity is calculated considering PV module degradation.

3. System's net present value, payback period and energy payback time are evaluated.

4. System's economic performance is compared to conventional generation in Bahrain.

\begin{abstract}
The electricity demand of Bahrain has been increasing rapidly in the recent years. At the present growth rate, the electricity peak demand is expected to reach $9500 \mathrm{MW}$ by 2030 . The cost of conventional generation in Bahrain, based on natural gas is comparatively high. The nature of the solar resource and energy demand in Bahrain is suggestive of large scale photovoltaics having significant potential for meeting the country's future electricity demand. The economic performance of a $1 \mathrm{MW}$ grid-connected photovoltaic (PV) system optimised for matching the daily peak load in Bahrain is analysed in this work in terms of levelised cost of electricity (LCOE), net present value (NPV), payback period (PBP) and energy payback time (EPBT). Results show a positive trend indicating that large scale photovoltaics could be a viable alternative for meeting future electricity demand. Even at current PV system prices the LCOE for the system designed was $43 \%$ less than the present actual cost of a kWh in Bahrain.
\end{abstract}




\section{Keywords}

Photovoltaics; Grid-connected; Levelised cost of electricity (LCOE); Net present value (NPV); Payback period (PBP); Energy payback time (EPBT)

\section{Introduction}

The Kingdom of Bahrain is a small GCC (Gulf Corporation Council) country in the MENA (Middle East and North Africa) region which has one of the best solar insolation conditions in the world. The energy consumption in Bahrain is increasing rapidly. The peak demand for 2015 was $3.4 \mathrm{GW}$ and the average peak demand growth rate was around $7 \%$ for the last ten years [1]. The peak demand is expected to reach $9.5 \mathrm{GW}$ by 2030 which means that Bahrain will need to more than double the existing power generation capacity in the coming $10-15$ years. Total installed power capacity of Bahrain is $4 \mathrm{GW}$, all of which depend on natural gas as the fuel for generation. It is worth mentioning that the consumer electricity prices in Bahrain are highly subsidised. The actual cost of a $\mathrm{kWh}$ is 28 fils $(\$ 0.074)$ while the consumer pays 3 fils if their consumption is below $3000 \mathrm{kWh} /$ month, 9 fils if it is below $5000 \mathrm{kWh} /$ month and 16 fils if the consumption is more than $5000 \mathrm{kWh} /$ month [2]. The total dependence on natural gas alone is not sustainable in the long run especially considering the high gap between the actual cost of electricity and the revenue from consumers. Bahrain needs to invest in more sustainable and cheaper energy sources.

The most widely utilised renewable energy resources in the world are wind and PV. Wind energy leads the renewable energy market with a share of $55.2 \%$ followed by PV with a share of $28.9 \%$ [3]. The countries that lead this growth are China, the United States, Japan and Germany which accounts for $70 \%$ of the total installed capacity [4]. Even though PV is an ideal candidate given the regions high annual irradiation, the countries in the MENA region are yet to have a significant PV uptake. In contrast, there has been a dramatic increase in the global 
uptake of large-scale grid-connected PV in the last few years due to factors such as falling prices and developments in large scale manufacturing [5].

In the literature, various authors have explored the techno-economic feasibility of either PV hybrid systems (in combination with another generation such as wind, diesel etc.) [6-8] or standalone PV systems [9-10], in middle-eastern climates. The techno-economics of PV systems for specific applications such as water pumping and desalination is explored in [11] and [12]. However, the number of studies examining the techno-economic feasibility of largescale grid-connected PV systems in the Middle East is limited and none in particular for Bahrain. Authors of [13] investigated 29 locations in Egypt to site a 10MW grid-connected PV plant. The study found that the lowest Levelised Cost of Electricity (LCOE) of $0.199 \$ / K W h$ was obtained for the location Wahat, Kharga. It was identified in [14] that an LCOE of 0.16 \$/KWh can be achieved for a 1MW PV power plant in Kuwait, if the system price was \$4/W. The authors of [15] focus on a utility scale PV project of $100 \mathrm{MW}$ in the United Arab Emirates (UAE), the study found out that using SdTe panels with 1-axis tracking at a cost of $1.8 \$ \mathrm{~W}$ for the PV system, the mean value of LCOE will be $0.1769 \$ / \mathrm{KWh}$.

From the electric power network perspective, it is of vital importance that any generator considered for accommodating future load growth is able to match peak demand. The system load curve, the conventional generation system and electricity pricing schemes are unique to Bahrain and quite distinctive from other nations having similar climates. Other studies in the literature consider the techno-economics of grid-connected PV for similar climates, with fixed capacities [16] or sizing optimised for energy yield or economics or installations constraints (e.g. building integration) [17]. There is little work reported on the techno-economics of systems optimised for peak demand. The aim and major contribution of this is paper is the determination of the economic viability of implementing a large scale grid-connected PV system with its orientation optimised to coincide the temporal peak of the daily system load curve, in Bahrain. The viability analysis is conducted in terms of 4 parameters: LCOE, Net 
present value (NPV), Payback period (PBP) and Energy payback time (EPBT). The results are expected to inform utility policies and investments in Bahrain.

The rest of the paper is organised as follows: section 2 describes the location selection, $\mathrm{PV}$ input data and system modelling along with the economic analysis methodology; results of the analyses are presented and discussed in section 3; finally, conclusions are drawn in section 4.

\section{Methodology}

\subsection{PV System Design and Simulation}

The solar resource assessment tool PVGIS (Photovoltaic Geographic Information System) from JRC (EU Joint Research Centre, Ispra) was used to identify the location in Bahrain with the best solar resource. The town of Zallaq (latitude 260 21' $\mathrm{N}$ and longitude $50049^{\prime} \mathrm{E}$ ) had the highest potential with an irradiation of $6250 \mathrm{Wh} / \mathrm{m}^{2} /$ day. A PV system size of $1 \mathrm{MW}$ was chosen for this study. The PV technology selected was poly-crystalline. Dusol modules were chosen for the design as they have started manufacturing facilities in GCC which will make it easier to source their modules. For grid integration, instead of using a single large inverter with capacity of $1 \mathrm{MW}, 5$ SMA Sunny Central inverters with a capacity of $200 \mathrm{~kW}$ each was used, the idea is to avoid operating inverter in its low efficiency regions when the output from PV array is low.

PVsyst software (V6.39) was used for design and optimisation of the PV system operation. PVsyst is an industrial standard software that has been validated for different climates and PV module and inverter technologies [18-20]. The software has facility to input meteorological data manually as well as import data from different databases. PVSyst considers a number of parameters affecting PV generation and can simulate the annual energy generation of a potential project site [21]. The $1 \mathrm{MW}$ PV system was simulated in PVsyst for the Zallaq region in Bahrain. The meteorological data for the location was collected by a satellite based GIS (Geographical Information System) system: PVGIS Climate -SAF (Photovoltaic Geographical 
Information System Climate Monitoring Satellite Application Facility). The data was imported from PVGIS Climate-SAF database to PVsyst to validate the sizing of the grid-integrated PV system and to understand the system performance.

In the Northern hemisphere, the collector plane of the PV array needs to be oriented to face south (azimuth $0^{\circ}$ ) and placed at a specific tilt angle to receive maximum solar radiation. It was found from PVsyst simulations that maximum output can be achieved from the PV array used in this study by choosing a tilt angle of $25^{\circ}$ and azimuth angle of $0^{\circ}$. However, one of the objectives of the system design was to achieve temporal coincidence of system peak load and PV generation peak. It was observed from the load profile of Bahrain that the peak load occurs between 1:00 P.M. and 4:00 P.M [22]. The generation peak for a PV design with a tilt angle of $25^{\circ}$ and azimuth angle of $0^{\circ}$ does not match the load peak. Changing the azimuth and tilt angles of the $\mathrm{PV}$ array to $35^{\circ}$ and $50^{\circ}$ respectively results in peak $\mathrm{PV}$ generation matching the load peak. The main parameters and outputs from the PVsyst system simulation are presented in Table 1.

Table 1. The main parameters of the $1 \mathrm{MW}$ PV system

\begin{tabular}{|l|l|}
\hline Parameters & Value \\
\hline PV module technology & Polycrystalline Silicon \\
\hline PV array total $P_{\text {nom }}$ & $1001 \mathrm{kWp}$ \\
\hline Cell area & $6083 \mathrm{~m}^{2}$ \\
\hline Inverter Nominal Power & $200 \mathrm{~kW}(\mathrm{ac})$ \\
\hline No. of inverters & 5 \\
\hline Produced Energy & $1641 \mathrm{MWh} /$ year \\
\hline
\end{tabular}

\subsection{Degradation Rate and System Lifetime}

The amount of energy generated by the PV system over its lifetime depends on its annual degradation rate. The annual degradation rate is very important in the economic viability analysis, because choosing a higher degradation rate will lead to a lower estimate of 
generated power and consequently reduced cash flow in the future. It was found that the actual in-field annual degradation rate for crystalline silicon PV cells is between $0.2-0.5 \%$ [23]. In this study, an annual degradation rate of $0.5 \% / y e a r$ was considered.

The system lifetime is equally important as the degradation rate. A lower degradation rate and longer system lifetime can increase the reliability of the system and will lead to reduced LCOE. Presently a more standard expectation of lifetime is 30 years for the system with 15 years inverter lifetime [24]. Fig. 1 shows the produced energy over the lifetime of the PV system. The total energy production of the system will be $45,822 \mathrm{MWh}$ with an average annual production of 1,527 MWh.

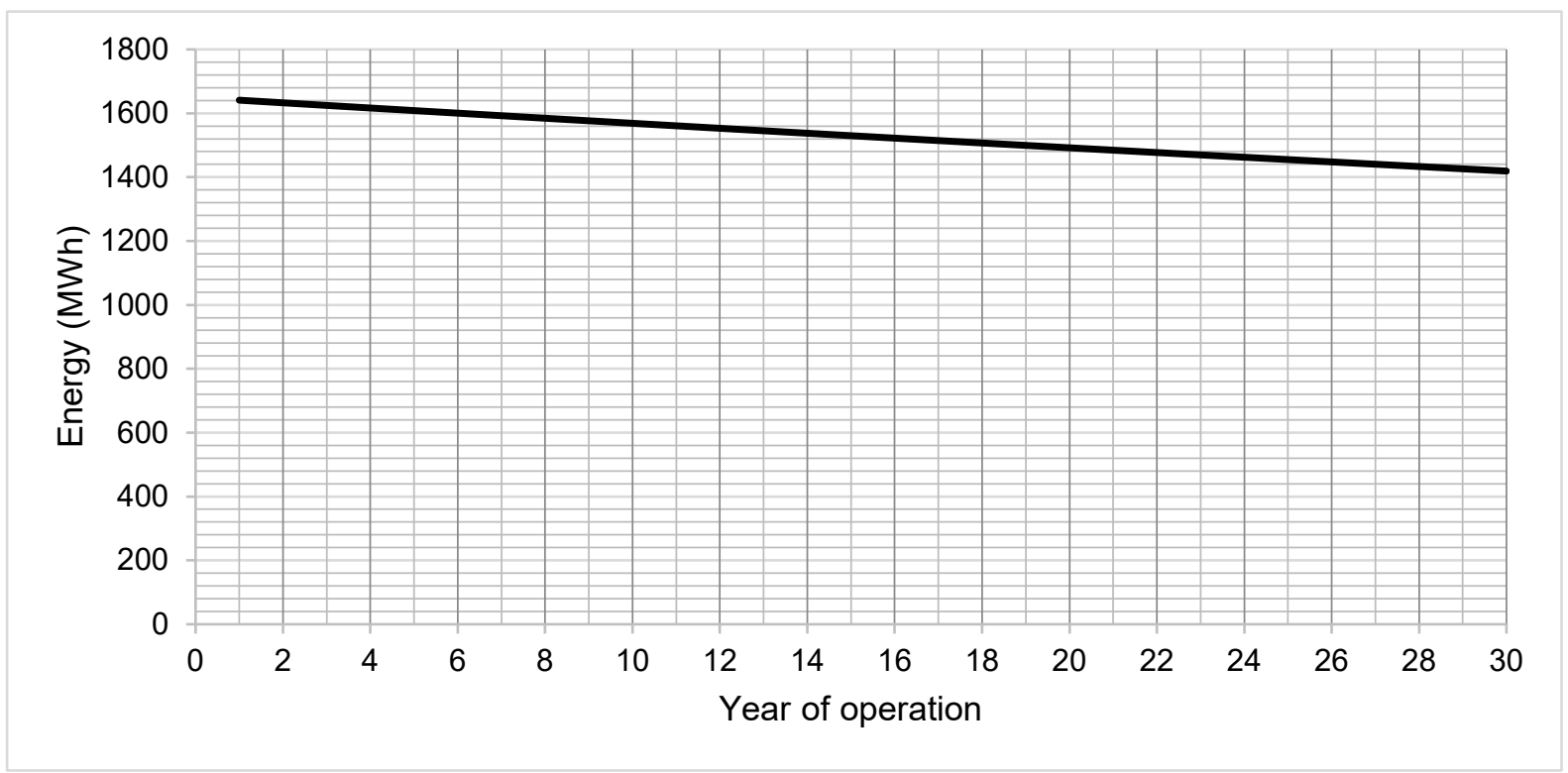

Fig. 1. Annual energy yield over system lifetime

\subsection{PV Economic Evaluation}

The main concern with a PV installation is that the costs must be recovered by means of sales of the energy generated by PV system during its lifetime. In addition to the PV module cost, the cost of mounting, wiring and installation which is called as Balance of System (BOS) and inverter cost should be considered in the calculation of the total cost of the system [24]. The breakdown of the installation cost of the $1 \mathrm{MW}$ PV system is shown in Table 2 . The parameters 
used for the economic evaluation and the calculation methodology are detailed in the following paragraphs.

Table 2. The breakdown of the installation cost of the PV system

\begin{tabular}{|c|c|}
\hline Item & Cost (\$/MW) \\
\hline Module & 0.65 \\
\hline Inverter & 0.15 \\
\hline BOS & 0.35 \\
\hline Total & 1.15 \\
\hline
\end{tabular}

\section{Levelised Cost of Electricity (LCOE)}

LCOE is as a long-term guide to competitiveness of energy generation technologies. The LCOE methodology is often used as a ranking tool as it can remove biases between technologies and assess the cost-effectiveness of different power generation technologies [25]. The LCOE can be calculated as a ratio of the total life cycle cost to the total lifetime energy production by the PV system as per the following equation [26]:

$$
L C O E=\frac{\text { Anual Cost }+O \& M}{\text { Annual Energy produced by the system }}
$$

Where O\&M is the operation and maintenance costs.

To calculate the annual cost of the system, a Capital Recovery Factor (CRF) which converts the present value of installation cost of the system into an equal annual cost over the period of the system lifetime, is used. So, the equation can be presented as [14]:

$$
L C O E=\frac{(\text { Installation } \text { Cost } \times C R F)+O \& M}{\text { Annual Energy produced by the system }}
$$

Where CRF is given by the equation:

$$
C R F=\frac{i \times(1+i)^{n}}{\left[(1+i)^{n}-1\right]}
$$


Where $i$ is the annual real interest rate and $n$ the lifetime of the system. The annual real interest rate is an interest rate after accounting for inflation, it is calculated as [27]:

$$
i=\frac{i^{\prime}-f}{1+f}
$$

Where $i$ ' is the nominal interest rate and $f$ is the annual inflation rate.

The nominal interest rate and inflation rate in Bahrain are $4.91 \%$ and $3.7 \%$ [28]. This leads to an annual real interest rate of $1.167 \%$. In this work an annual O\&M cost of $15 \$ / \mathrm{kW}$ of installed capacity is considered.

\section{Net present value (NPV)}

Net present value (NPV) is a very important parameter in determining the economic feasibility of an investment as it represents the net profit generated. A positive NPV indicates that it would be economically beneficial to invest in the project. NPV is the difference between the present value of cash flows over the life time of the project and the initial capital cost. NPV can be determined from the following equation [29]:

$$
N P V=\sum_{t=0}^{N} \frac{\text { Revenue }}{(1+i)^{t}}-\text { Intial Cost }
$$

Where $N$ is the number of years for the economic analysis which is normally the project lifetime, $t$ is the year and $i$ is the interest rate. The annual revenue can be calculated by multiplying the annual energy produced by the PV system with the energy price. The annual revenue can be calculated by the following equation [30]:

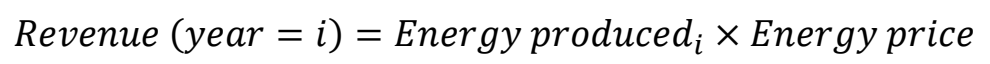

The per unit energy price was considered as constant over the system lifetime at $28 \mathrm{fils} / \mathrm{kWh}$ $(0.074 \$ / \mathrm{kWh})$ in this study. 


\section{Payback period (PBP):}

PBP is used to determine the expected time required for the project to recover its initial cost. A shorter PBP time will be better, because the project recovers the initial cost in a short timeframe. PBP is equal to the time that is required to make NPV equal to zero. To calculate PBP, firstly it has to be checked if the total NPV of the project over its life time is negative. If it is, that means the project isn't feasible. If NPV is positive then the parameter $N$ in (6) is decremented in steps of 0.25 years and NPV is calculated for each step until the NPV equal to zero, at which time $\mathrm{N}$ becomes equal to PBP.

\subsection{The Energy Payback time (EPBT):}

The Energy Payback time (EPBT) is a techno-economic parameter used to represent the energy performance of different power generation technologies. EBPT is the time required for the PV system considered to produce the same amount of energy as that was used to produce the PV system. The EPBT is defined as a ratio between the life cycle energy requirement, which is the energy need during installation, operation, and decommissioning- and the annual energy generated by the system. Therefore, the EPBT can be calculated using the following equation [31]:

$E P B T=\frac{\text { Embedded }(\text { primary)energy }}{\text { Annual }(\text { primary }) \text { energy generated by the system }}$

The results of the LCOE, NPV, PBP and EPBT analyses are reported in the next section.

\section{Results and Discussion}

\subsection{Levelised Cost of Electricity}

The LCOE for the $1 \mathrm{MW}$ PV system in Zallaq with its orientation optimised for peak load matching was calculated based on the parameters shown in Table 2 and considerations mentioned in Table 3. The results show that the LCOE value is $0.0423 \$ / \mathrm{kWh}$ (16 fils). It has to be kept in mind that the ambient temperature conditions for PV system operation in Bahrain is high and affects the performance and efficiency of the PV system negatively, as the cooling 
system considered was natural air-cooling. Even despite this, the LCOE is $43 \%$ less than the present actual cost of a $\mathrm{kWh}$ in Bahrain, which is equal to 28 fils. Hence it is safe to say not only that largescale PV systems can provide peak load matching under the climatic conditions, but also that it is highly financially viable as a future electricity generation option for Bahrain especially from the grid perspective.

Table 3. Considerations for LCOE calculation

\begin{tabular}{|l|l|}
\hline Item & Value \\
\hline System lifetime (years) & 30 \\
\hline Inverters life time (years) & 15 \\
\hline Total energy generated (MWh) & 45,822 \\
\hline Interest rate & 0.0491 \\
\hline Inflation rate & 0.037 \\
\hline Real Interest rate & 0.011668 \\
\hline CRF & 0.039699 \\
\hline O \& M cost (\$/kW/year) & 15 \\
\hline PV module installation cost (\$) & 650,000 \\
\hline Inverter installation cost (\$) & 250,000 \\
\hline BOS installation cost (\$) & 350,000 \\
\hline Total installation cost (\$) & $1,250,000$ \\
\hline O \& M cost (\$/Year) & 15,000 \\
\hline Annual cost (\$) & 64,624 \\
\hline
\end{tabular}

A liquid cooling system (such as water-cooling) can increase the energy output. This will bring a net positive impact on the LCOE only if the associated increase in operation and maintenance cost remains the same per unit of energy generated. As the system considered in this study is static, the major share of the operation and maintenance cost goes towards cleaning of the system. The impact of the cleaning regime and dust on PV performance can only be ascertained by long term outdoor filed performance studies. As such studies were not yet available for Bahrain, the annual degradation rate used for the analysis was kept at the 
top of the range (0.5\%/year) described for crystalline silicon PV cells in [23].

The impact of the cost of land, building of new transmission lines, substation etc. for evacuation of power is common for any new generation and should not be a constraining factor. Since the peak load growth necessitates new generation.

\subsection{Net Present Value}

The NPV analysis was conducted based on the costs, interest rate and other parameters mentioned in Table 3. The result shows that the present value of revenues from the PV system investment will be $\$ 2,412,334$, while the NPV of the investment is positive and will be equal $\$ 1,512,334$ for a system lifetime of 30 years. The profits from the system of $\$ 1,512,334$ is considerable and should assure investors in Bahrain that $\mathrm{PV}$ is a viable potential investment. Fig. 2 and 3 show the changes in cumulative revenue and NPV over the system lifetime. As can be seen from Fig. 3, the profits from the system is considerable compared to the initial investment. As the system is static, unlike other conventional or renewable sources of energy, the operation and maintenance cost does not increase steeply towards end of the system lifetime. Considering an annual degradation rate of $0.5 \% / y e a r$ at the end of 30 year, the PV array in the system would still be capable of producing $0.85 \mathrm{MW}$ peak. The inverter will need replacing owing to its shorter lifetime. However, if that additional cost is borne by the system owner the profits can be extended to a further period until the system is fully decommissioned.

\subsection{Pay Back Period}

The payback period for the proposed $1 \mathrm{MW}$ in Zallaq was found to be 9.25 years. Given the system lifetime of 30 years this payback period is highly attractive. The high profits (NPV) and short PBP should be conducive for large scale PV investments in Bahrain. As PV module prices are continuing to drop the future NPV and PBP is expected to become further attractive. The government policy on interest rates for renewable energy investments will have a significant impact on payback rates. Interest subsidies will lead to the payback period becoming shorter than the 9.25 years calculated. However, the results also highlight the fact even under the current Central Bank of Bahrain interest rates, which has been used in this 
study, the proposed system is viable. Hence, it is safe to say that while policies leading to interest subsidies will promote PV investments in Bahrain, it is not crucial for economic viability of centralised largescale PV installations.

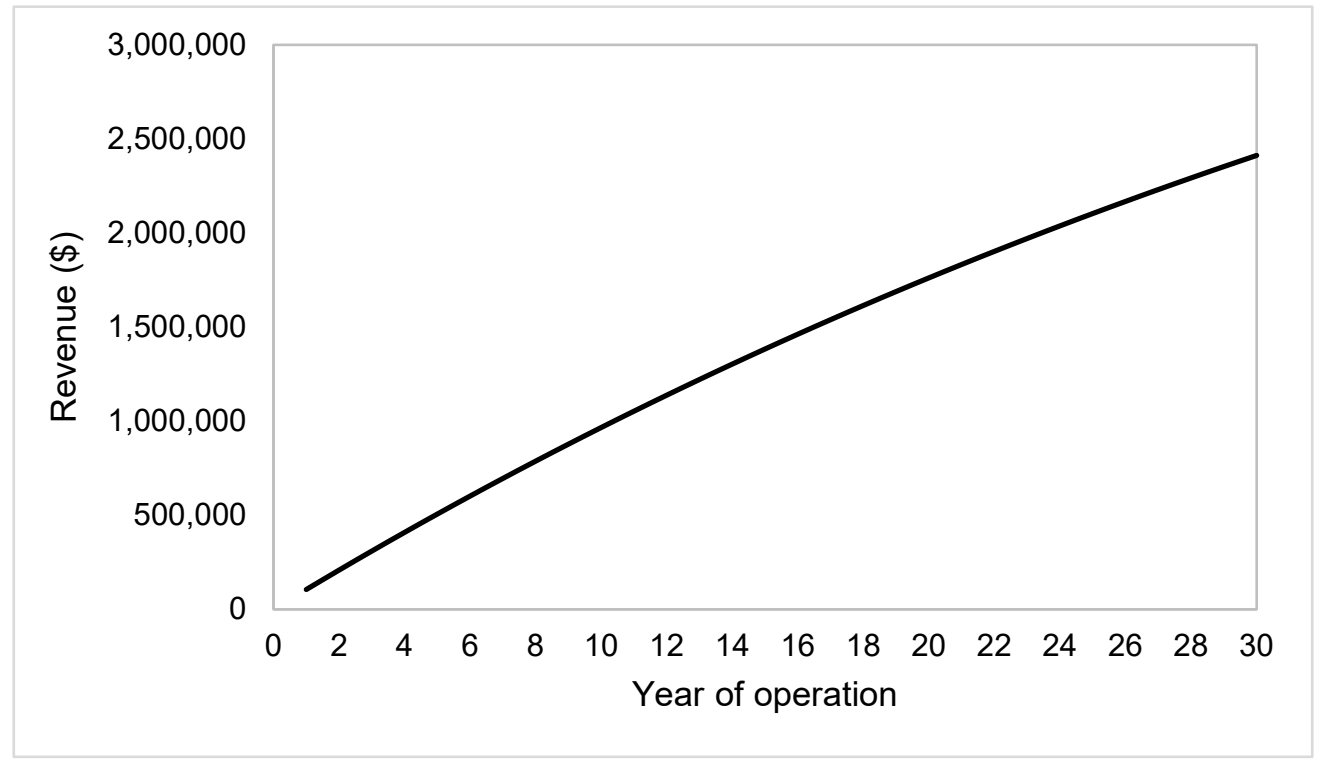

Fig 2. Cumulative present value of revenue from the $1 \mathrm{MW}$ PV system over its lifetime

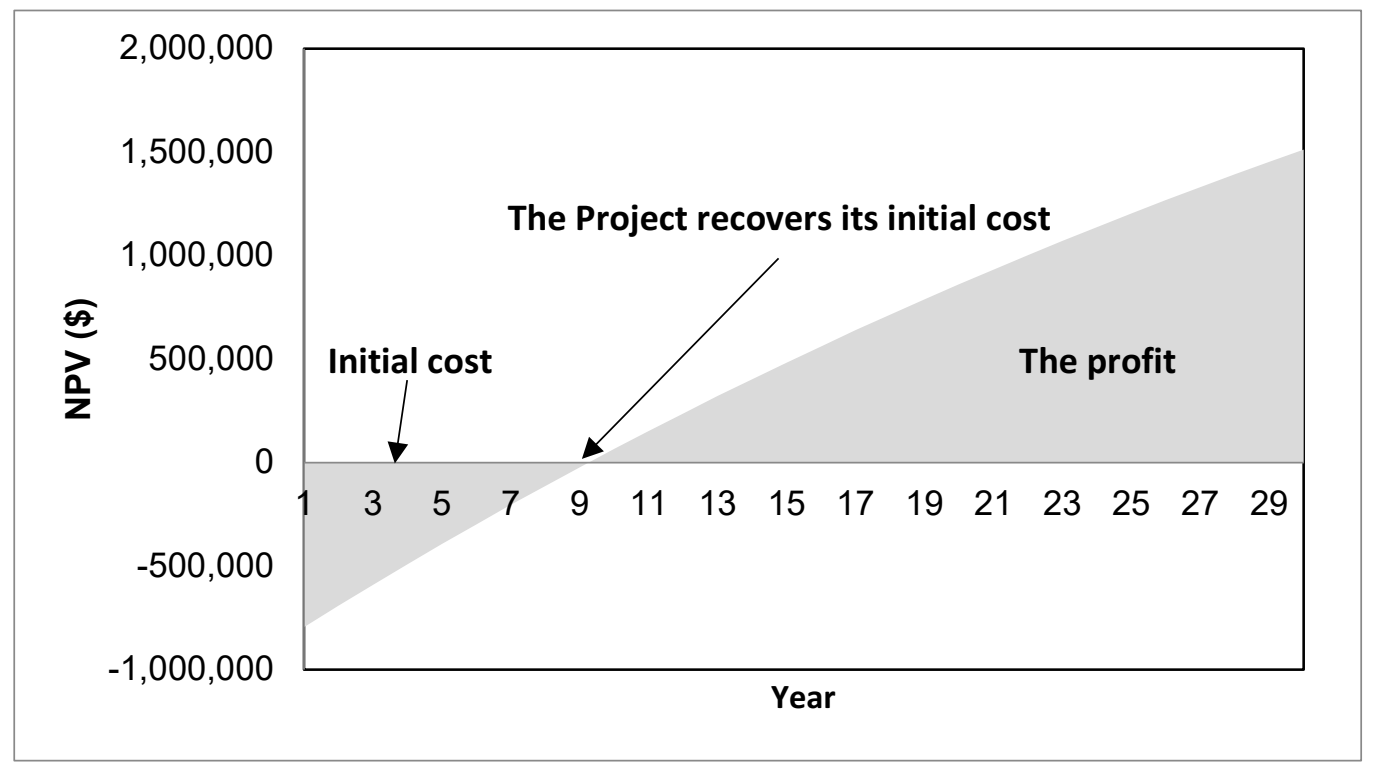

Fig 3. NPV of the 1MW PV system investment over its lifetime 


\subsection{Energy Payback Time}

The best estimate of embedded energy for crystalline silicon modules is $600 \mathrm{kWh} / \mathrm{m}^{2}$ [32]. Hence, the total embedded energy of the proposed $1 \mathrm{MW}$ grid connected PV system will be equal to 3,650 MWh. Based on the cumulative annual energy generation by the PV system as shown in Fig. 4, the EPBT will be 2.7 years i.e. the amount of energy needed for the production of the proposed PV system can be fully recovered in 2.7 years under the irradiance and temperature conditions of the location in Bahrain. For more than 27 years of operation of the PV system it will be emission free and energy positive indicating that PV is a highly sustainable power generation technology. Bahrain currently has a very high per capita $\mathrm{CO}_{2}$ emission of 21.8 tonnes [33] and is fourth in the world in terms of per capita emissions. The reliance on natural gas as the source for electricity generation is one of the contributing reasons. It is evident from the analysis with the proposed system that with a gradual switch to PV, it is possible to considerably lower the $\mathrm{CO}_{2}$ emissions while matching the power system peak load. This also means that the current load behaviour of electric power network customers can be permitted to continue undisrupted with regards to carbon emission reduction.

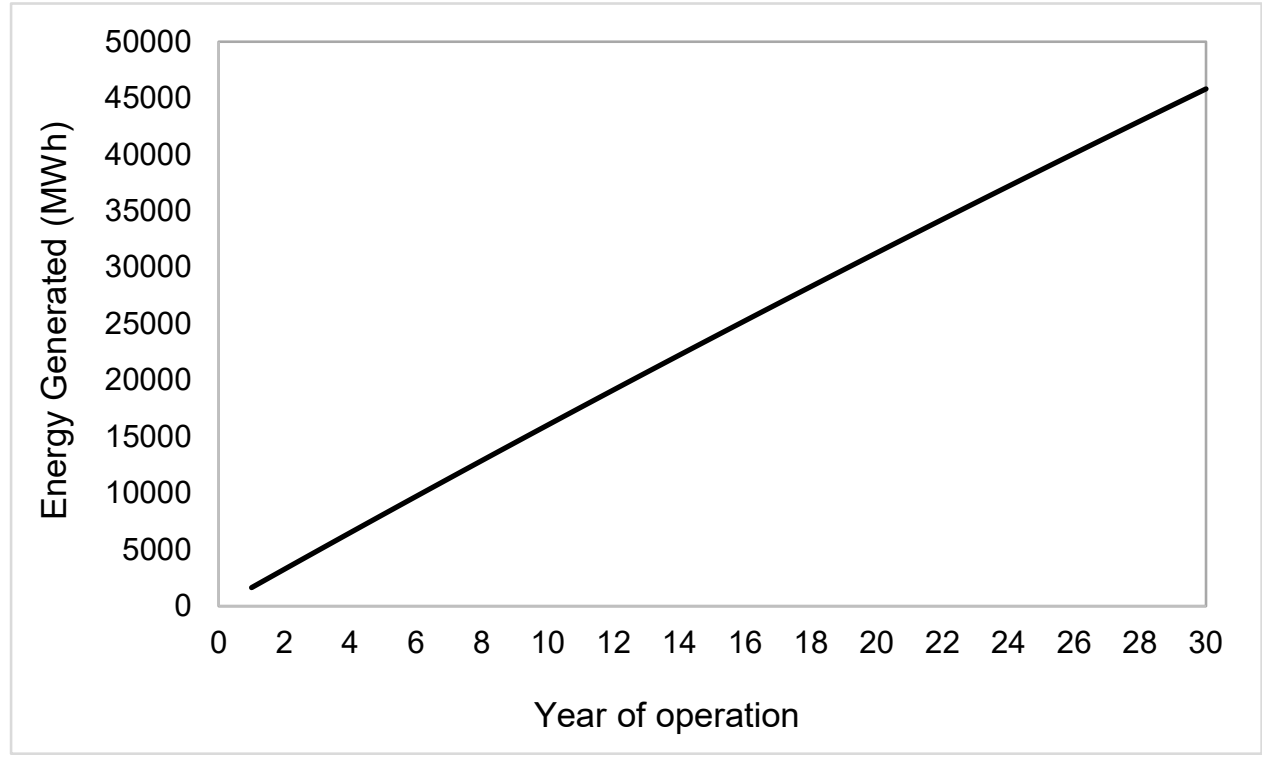

Fig 4. The cumulative annual energy generation by the $1 \mathrm{MW}$ PV system

\section{Conclusions}


The electricity demand of Bahrain is rapidly increasing and if the growth maintains current rate the electricity peak demand is expected to reach 9500 MW by 2030 which necessitates the addition of more power generation capacity to the energy system. Given the present reliance on natural gas power plants, large scale grid connected PV systems could offer a sustainable capacity expansion solution reducing dependence on the fossil fuel. A large scale gridconnected PV system in Bahrain with its orientation optimised to coincide the temporal peak of the daily system load curve was considered in this study. The viability of the PV system to be an energy positive and sustainable source and a financially attractive investment was analysed in terms of LCOE, NPV, PBP and EPBT. The results showed a strongly positive indication for the $1 \mathrm{MW}$ PV grid connected system considered. The LCOE was found to be $0.0423 \$ / \mathrm{kWh}$ (16 fils $/ \mathrm{kWh}$ ) which is $43 \%$ less than the present actual cost of a $\mathrm{kWh}$ of generation in Bahrain. Based the results of the analyses presented in this work, implementation of largescale grid connected PV systems to reduce the cost of power generation and diversification the electrical energy source is recommended in Bahrain.

Whilst policies leading to interest subsidies for renewables will be able promote PV installations in Bahrain, it is evident from the LCOE, NPV and PBP values that it is not crucial for economic viability of centralised largescale PV installations at current PV module and rest of system prices. This is without factoring in the cost of land, building of new transmission lines, substation etc. It is also evident from this study that it possible to have a sustainable energy transition, reducing carbon emissions, without disrupting the current load behaviour of electric power network customers by optimising largescale PV systems in Bahrain for the system load curve. It is recommended that in the near future, in order to understand the impact of local weather conditions such as dust and high urban ambient temperatures, and to identify the annual degradation rate, appropriate cleaning regimes and system cooling methods a field performance study using grid-connected PV systems be carried out. 


\section{References}

[1] "Power consumption surges 9.2pc in Bahrain", Tradearabia.com, 2017. [Online]. Available: http://www.tradearabia.com/news/OGN_289281.html. [Accessed: 10- Jun- 2017].

[2] N. Alnaser, "Building integrated renewable energy to achieve zero emission in Bahrain", Energy and Buildings, vol. 93, pp. 32-39, 2015.

[3] "Renewables 2016 Global Status Report", 2017. [Online]. Available: http://www.ren21.net/wpcontent/uploads/2016/06/GSR_2016_Full_Report_REN21.pdf. [Accessed: 10- Jun- 2017].

[4] "As European Solar Installations Slow, China, US and Japan Lead Global Installed PV Capacity in 2016, IHS Says | IHS Online Newsroom", Press.ihs.com, 2017. [Online]. Available: http://press.ihs.com/pressrelease/european-solar-installations-slow-china-us-and-japan-lead-global-installed-pv-capacity. [Accessed: 10Jun- 2017].

[5] T. Nacer, A. Hamidat, O. Nadjemi and M. Bey, "Feasibility study of grid connected photovoltaic system in family farms for electricity generation in rural areas", Renewable Energy, vol. 96, pp. 305-318, 2016.

[6] A. Maleki and A. Askarzadeh, "Optimal sizing of a PV/wind/diesel system with battery storage for electrification to an off-grid remote region: A case study of Rafsanjan, Iran", Sustainable Energy Technologies and Assessments, vol. 7, pp. 147-153, 2014.

[7] A. Al-Badi, M. Albadi, A. Malik, M. Al-Hilali, A. Al-Busaidi and S. Al-Omairi, "Levellised electricity cost for wind and PV-diesel hybrid system in Oman at selected sites", International Journal of Sustainable Engineering, vol. 7 , no. 2, pp. 96-102, 2014.

[8] F. Diab, H. Lan, L. Zhang and S. Ali, "An environmentally friendly factory in Egypt based on hybrid photovoltaic/wind/diesel/battery system", Journal of Cleaner Production, vol. 112, pp. 3884-3894, 2016.

[9] A. Al-Salaymeh, Z. Al-Hamamre, F. Sharaf and M. Abdelkader, "Technical and economical assessment of the utilization of photovoltaic systems in residential buildings: The case of Jordan", Energy Conversion and Management, vol. 51, no. 8, pp. 1719-1726, 2010.

[10] I. Askari and M. Ameri, "Techno-economic Feasibility Analysis of Stand-alone Renewable Energy Systems (PV/bat, Wind/bat and Hybrid PV/wind/bat) in Kerman, Iran", Energy Sources, Part B: Economics, Planning, and Policy, vol. 7, no. 1, pp. 45-60, 2012.

[11] S. Rehman and A. Sahin, "Performance Comparison of Diesel and Solar Photovoltaic Power Systems for Water Pumping in Saudi Arabia", International Journal of Green Energy, vol. 12, no. 7, pp. 702-713, 2014.

[12] A. Al-Karaghouli, D. Renne and L. Kazmerski, "Technical and economic assessment of photovoltaic-driven desalination systems", Renewable Energy, vol. 35, no. 2, pp. 323-328, 2010.

[13] M. EL-Shimy, "Viability analysis of PV power plants in Egypt", Renewable Energy, vol. 34, no. 10, pp. 21872196, 2009.

[14] M. Ramadhan and A. Naseeb, "The cost benefit analysis of implementing photovoltaic solar system in the state of Kuwait", Renewable Energy, vol. 36, no. 4, pp. 1272-1276, 2011.

[15] A. Hussain, T. Mezher and S. Griffiths, "Economic assessment of large scale solar photovoltaic projects in the UAE", 2013 International Conference on Engineering, Technology and Innovation (ICE) \& IEEE International Technology Management Conference, 2013.

[16] E. Harder and J. Gibson, "The costs and benefits of large-scale solar photovoltaic power production in Abu Dhabi, United Arab Emirates", Renewable Energy, vol. 36, no. 2, pp. 789-796, 2011.

[17] S. Sharples and H. Radhi, "Assessing the technical and economic performance of building integrated photovoltaics and their value to the GCC society", Renewable Energy, vol. 55, pp. 150-159, 2013.

[18] T. Gerstmaier, M. Gomez, A. Gombert, A. Mermoud and T. Lejeune, "Validation of the PVSyst performance model for the Concentrix CPV technology", in AIP Conference, 2011, vol. 1407, pp. 366-369.

[19] N. Van der Borg and M. Jansen, "Energy loss due to shading in a BIPV application", in 3rd World Conference on Photovoltaic Energy Conversion, 2003, vol.3, pp. 2220-2222.

[20] A. Mermoud, "Use and validation of PVSYST, a user-friendly software for PV-system design", in 13th European Photovoltaic Solar Energy Conference, 1995.

[21] A. Almasoud and H. Gandayh, "Future of solar energy in Saudi Arabia", Journal of King Saud University Engineering Sciences, vol. 27, no. 2, pp. 153-157, 2015.

[22] G. Pillai and H. Naser, "Assessing the technical impact of integrating largescale photovoltaics to the electrical power network of Bahrain", Sustainable Energy Technologies and Assessments, vol. 20, pp. 78-87, 2017. 
[23] D. Jordan and S. Kurtz, "Photovoltaic Degradation Rates - An Analytical Review", 2012. National Renewable Energy Laboratory, USA. [Online]. Available: http://www.nrel.gov/docs/fy12osti/51664.pdf. [Accessed: 10- Jun2017].

[24] M. Woodhouse, R. Albertus, D. Feldman, R. Fu, K. Horowitz, D. Chung, D. Jordan, S. Kurtz, "The Role of Advancements in Solar Photovoltaic Efficiency, Reliability, and Costs", 2016. National Renewable Energy Laboratory, USA. [Online]. Available: http://www.nrel.gov/docs/fy16osti/65872.pdf. [Accessed: 10- Jun- 2017].

[25] K. Branker, M. Pathak and J. Pearce, "A review of solar photovoltaic levelized cost of electricity", Renewable and Sustainable Energy Reviews, vol. 15, no. 9, pp. 4470-4482, 2011.

[26] G. Smestad, "The basic economics of photovoltaics for vacuum coaters", in 52nd Annual Technical Conference, San José, CA, 2009.

[27] M. Ngan and C. Tan, "Assessment of economic viability for PV/wind/diesel hybrid energy system in southern Peninsular Malaysia", Renewable and Sustainable Energy Reviews, vol. 16, no. 1, pp. 634-647, 2012.

[28] Central Bank of Bahrain, "Economic Indicators", 2015. [Online]. Available:

http://www.cbb.gov.bh/assets/E\%20I/El\%20Jun2015.pdf. [Accessed: 10- Jun- 2017].

[29] E. Drury, P. Denholm, R. Margolis, "The Impact of Different Economic Performance Metrics on the Perceived Value of Solar Photovoltaics", 2011. National Renewable Energy Laboratory, USA. [Online]. Available: http://www.nrel.gov/docs/fy12osti/52197.pdf. [Accessed: 10- Jun- 2017].

[30] A. Audenaert, L. De Boeck, S. De Cleyn, S. Lizin and J. Adam, "An economic evaluation of photovoltaic grid connected systems (PVGCS) in Flanders for companies: A generic model", Renewable Energy, vol. 35, no. 12, pp. 2674-2682, 2010.

[31] K. Bhandari, J. Collier, R. Ellingson and D. Apul, "Energy payback time (EPBT) and energy return on energy invested (EROI) of solar photovoltaic systems: A systematic review and meta-analysis", Renewable and Sustainable Energy Reviews, vol. 47, pp. 133-141, 2015.

[32] E. Alsema, "Energy Requirements and CO2 Mitigation Potential of PV System", Urecht University, The Netherland, 2006. [Online]. Available:

http://dspace.library.uu.nl/bitstream/handle/1874/7966/98054.pdf?sequence=1. [Accessed: 10- Jun- 2017].

[33] The Telegraph, "How does Britain compare with the rest of the world when it comes to pollution?", 2017. [Online]. Available: http://www.telegraph.co.uk/travel/maps-and-graphics/co2-emissions-per-capita-ranking/ [Accessed: 10- Nov- 2017]. 